\title{
Emotion as the Foundation of Creativity
}

\author{
Nenad Suzic
}

\begin{abstract}
The starting point for this study was the hypothesis that creativity is connected with emotions. The author applied $\operatorname{CogAT}$, a widely known instrument for measuring creativity, calibrated it on the observed sample, and obtained a high level of internal consistency, as measured using Cronbach's alpha coefficient $(\alpha=\mathbf{0 , 8 3})$. In addition, he drafted his own instrument called CREM, measuring creativity and emotions. It was also calibrated using Cronbach's alpha coefficient and obtained satisfactory coefficients $(\alpha=0,50$ for tasks in a mathematics textbook, $\alpha=0,83$ for positive emotions and $\alpha=0,78$ for negative emotions). Crossing variables showed that creativity is in fact driven by emotions, but more by negative than positive ones. The stability of the correlation was tested measuring the effect size. It turned out that the correlation increased over time $(r=-0,41$ to $r=-0,88)$. This is indeed logical - the longer we carry a problem, the more frustration will grow over not finding a solution. What remains is to explore whether a creative solution elicits positive emotions.
\end{abstract}

Index Terms - divergent production; emotional intelligence; negative emotions; positive emotions.

\section{INTRODUCTION}

The greatest discoveries in human history were driven by emotions. We divide human reasoning to deductive and inductive. According to Radivoj Kvaščev [38], deductive reasoning does not yield creativity. Deduction is prevalent in school, which is primarily because the teacher appropriates reasoning, i.e. denies students any possibility to think on their own [38, p. 39]. Essentially, creativity is first and foremost originality, and according to Kvaščev, originality can be trained and learned [38, p. 39]. Emotions have been ousted from schools [28], [26]. In other words, schools do not harbour creativity because they suspend emotions. Rigidity is the main obstacle to creativity [61], and schools are hugely rigid.

Over time, people have developed cognition, while neglecting emotions. Oswald Spengler claimed that people have suppressed many emotions during evolution [68]: Fear of cannibalism, fear of freezing, fear of hunger, fear of thunder etc. Emotions determine the quality of our lives [24]. If statement by Paul Ekman is true, we must wonder why emotions are discouraged in schools. The answer is simple: It is easier to deal with cognition. Specifically, the cognitive effects of teaching are much more easily measured than the emotional ones. And yet, research has shown that we can learn how to recognize and control emotions [22], [24], [31], [72], [73].

Positive emotions reinforce pro-social behaviour [12]. Research has shown that children prone to intense negative emotions have a hard time managing their anger [23]. If adolescents are frustrated in the workplace, they adopt antisocial behaviour patterns all the more easily [67]. In addition, adolescents tend to blame their anger on others [58]. This and similar studies show that repressing negative emotions is socially conditioned, so we can assume that evolution has brought about physiological changes which have enabled humans to suppress negative emotions and evoke positive ones more easily.

Those who tend to hide any emotion are prone to asocial behaviour [29]. Schools support the development of rational reasoning, but not emotional reasoning. It is a disturbing fact that we can observe progress in the cognitive development of children, while at the same time there is a decline in emotional intelligence [72]. This results from the fact that schools across the board neglect emotions. There are many families where emotions are neglected. In the 20th century, there were more successful people with high EQs than with high IQs [31]. It is not surprising, because emotions have been systematically repressed throughout human history. For instance, they are still elusive for today's education system. Even though man has evolved and survived thanks to centres in the brain which have preserved basic emotions, today we are witness that they are studied very little [31].

\section{EMOTIONAL INTELLIGENCE}

If we were to integrate emotional intelligence into the education system, if we promote and practise active participation of the students in the teaching process and create a community of integrated learning, education cannot fail [42]. Empirical research findings indicate that emotional intelligence significantly impacts performance in school [37]. Specifically, fear of failure and motivation for learning in school are closely tied to specific teaching tasks [37]. Emotional intelligence is connected to self-regulation and optimization of individual goals [65]. Some authors believe that regulation of one's own emotions and "reading" the emotions of others are key components in determining the level of emotional intelligence [63]. Research and ideas of several authors indicate that emotional intelligence is significant for performance at work [1], [13], [31], [32], [66]. In addition, some studies show that emotional intelligence significantly impacts academic performance [10], [40]. It is peculiar that even with all these findings, emotional intelligence still hasn't found its place in the school system, even more so since we know that humans begin to communicate with their environment from birth. Specifically, a baby will cry if it is hungry or needs changing, and crying 
is a reflection of emotion.

An interesting definition of emotional intelligence was given by Salovey and Mayer, who say it is "the subset of social intelligence that involves the ability to monitor one's own and others' feelings and emotions, to discriminate among them and to use this information to guide one's thinking and actions" [63]. Simply being high in emotional intelligence does not guarantee a person will have learned the emotional competencies that matter for work; it means only that they have excellent potential to learn them [31]. Emotional competences are twice as significant for efficient achievements than cognitive ones [31]. Emotions quickly overrun our cognition, often ignoring it. They sometimes overrule everything we know [24]. It is comforting to know we can learn to control our emotions [20], [24], [31], [33], [38], [49], [60].

From a broad variety of emotions, authors have singled out the basic ones. Robert Plutchik distinguished eight basic emotions in his so-called "radial model": (1) joy, (2) anticipation, (3) anger, (4) disgust, (5) sadness, (6) surprise, (7) fear and (8) trust (Plutchik, 1980). Paul Ekman distinguished seven primary emotions: (1) sadness, (2) anger, (3) surprise, (4) fear, (5) disgust, (6) contempt and (7) enjoyment [24]. Anne Richards et al. provide a continuity of six emotions: (1) joy, (2) anger, (3) disgust, (4) sadness, (5) fear and (6) surprise [59]. Just as animals do, people express basic emotions spontaneously. Daniel Goleman's general conclusion is that emotional intelligence is twice as significant for professional success than cognitive intelligence [31]. Schools are focused on preparing students to pass tests and get passing grades, while neglecting their emotions and creativity [64]. Is it possible to do something today to change this stereotype in schools?

Yes, it is. Research has given positive incentives. When emotional intelligence training was introduced in a business school, it turned out the students developed better interpersonal and intrapersonal communication abilities [44]. Research has found that emotions do indeed improve memory and creativity. For example, a series of studies were carried out in the memory sphere confirming the hypothesis: stories presented through emotions [34], film clips [11], emotional words [39], images [7], 4] etc. In the creativity segment, research indicates that emotions are an integral part of creativity [36]. It was back in 1973 that David McClelland pointed out that people with special abilities (stars) aren't only talented in the cognition sphere, but primarily in the emotionalness sphere [45].

\section{CREATIVITY}

What is creative thinking and what is its purpose? Creative thinking refers to processes underlying production of creative products, which are novel works - or innovations - brought about through goal-directed activities [77]. Children who ask questions in school are more creative than those who don't. Originality can be practised [38]. The foundation of creativity is most commonly emotion, which is something one can learn [24], [64]. However, schools do not encourage children to ask questions. In fact, questions by children in school are not desirable. Teaching people to think means teaching people to ask questions [64]. A study by Vladimir Jurić found that the student's question in class encourages: (1) the child's cognitive development, (2) increased divergent production and (3) increased class efficiency [35]. He warns of the possibility that by over-emphasizing the importance of student questions may lead to neglecting teacher questions (1974), which is why he advocates for a balanced approach. Schools strongly promote cognition, founding the encouragement on fear. However, fear often results in cognitive misconceptions and blockages [5], [9], [26]. If we encourage children to ask questions in class, we reduce their fear. We can encourage students to ask questions which inspire wonderment. This will contribute to the creation of a relaxed atmosphere in the classroom. Humans have a primordial need for wonderment [64, p. 39]. There are countless lessons that we can impart on children in the form of wonderment. Questions lead to new thoughts, answers only conclusions, i.e. to the end of thinking [64, p. 40]. It makes sense at this point to wonder which skills we should develop in children to direct them towards creativity. The answer comes from Mihaly Csikszentmihalyi. They are; (1) imaginativeness, (2) general abilities and (3) knowledge [19].

When we include students in active participation in classes, we encourage their critical thinking and imaginativeness [74]. Cognitive and emotional involvement of the children augments the outcomes of education [17], [46]. A study by Joseph Betts et al. found that the interpersonal relationship of the student and the teacher is a key factor for student participation in classes [6]. In addition to the student-teacher relation, another crucial factor is peer support, because it encourages students' critical thinking and emotional ease [8].

A student who is willing to ask questions in class risks looking dumb or stupid in front of their peers. Creativity and risk go hand in hand [64]. A teacher should encourage children with the idea that there are no dumb questions, only dumb answers. Modern-day schools are afflicted by a stereotype: schools and teachers don't fail, only students fail [64, p. 59, p. 61]. Creativity is directly linked with divergent production. You cannot be creative unless you are curious about everything [64, p. 61].

America was discovered in 1492. This fact can prompt students to make a series of creative questions, such as, Has someone discovered America before 1492, or What would have happened if America hadn't been discovered, or What if Native Americans had discovered Europe first etc. If we encourage children to ask these sorts of questions, it will make it easier for them to remember the year 1492 and all the circumstances of the discovery of America. A technique which works great in encouraging creativity is contrasting [See workshop KIP, 70]. Each argument made by a teacher must be countered by students. For example, if the teacher says two and two are four, the student may ask "And what if it is five or three?" The first part of the question leads us to Riemannian geometry, whereas the second part goes towards Lobachevskian geometry. Of course, this is beyond the students' grasp, but they could fathom the existence of alternative solutions. There are always alternative solutions, if we keep an open mind. Often, alternative solutions are better than existing ones. The only question is how willing we are to consider them.

There can be no creativity without divergent production. The core of divergent production is in man's willingness to 
think outside the box. An idea to solve a problem need not bring a solution which is better than the existing one - that is the point of divergent production. What is important is to provide an alternate, not necessarily a better solution.

The first papers on divergent production can be traced back to [30]. He categorized divergent production under operations (see Figure 1). The greatest name in the field of divergent production of today is Ken Robinson. In his research, he found that as children get older, their creativity declines [60]. He believes that divergent production is the foundation of creativity [60]. Indeed, it is impossible to be creative without making mistakes. Divergent production means finding an alternative solution, not necessarily a better one. In order for a person to be creative, they need to have potential for divergent production [19]. I had a class on "Precipitation" in the fifth grade of elementary school (equivalent to today's sixth grade: age 10-11). I asked the children why rain falls to the ground. They explained that at the altitude of 4500 meters above sea level, water vapour condenses due to low temperatures, forms into droplets and falls to the ground in the form of rain. I told them to stop with such explanations, that they were children, and not scientists. I told them rain falls down because it doesn't have ladders to climb down. They laughed out loud, and a shower of ideas ensued: angels were showering, St. Peter was watering his flowers etc. One of the students raised her hand and asked: "Sir, will I get an A in the test if I answer the question like that?" I responded of course, because I wasn't grading their knowledge, but their imagination. They were thrilled and true brainstorming began. I encouraged them to ask as many questions as they could. I explained that the questions didn't have to be "smart", that they could ask anything they thought of. I wrote down some of these questions on the blackboard. For example, why does it snow in the winter instead of raining? Then I divided the class into five groups and assigned three questions from the board to each group. I told them they could find the answers in the textbook. Their task was to explain these questions as if they were

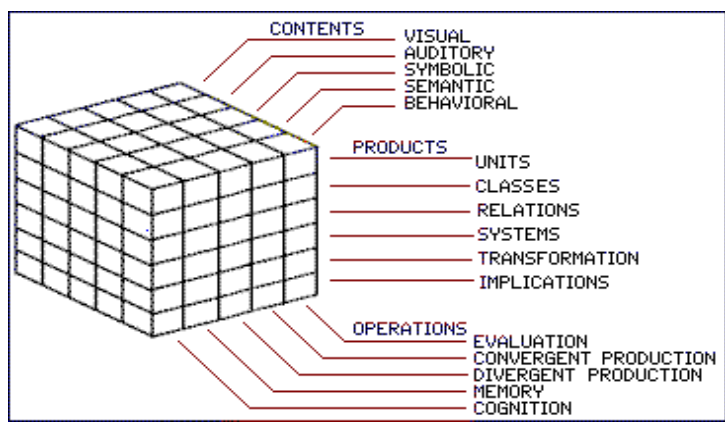

Fig. 1.: Guilford's model of human competences.

Teacher, i.e., to the best of their abilities. They were allowed to use their textbooks in preparing their presentations. They had five hours of geography that day. After the second hour they had a long recess. The sandwiches for lunch arrived. One of the boys asked if his group could carry on working through recess. I told them it wouldn't be OK to get grease on their notebooks and textbooks and suggested they eat their sandwiches first. He was persistent and promised they would look after their notebooks and textbooks. The door of this particular classroom opened towards the hall, which the teachers had been using as a break room instead of the teachers' assembly room. During the recess we were having our coffee, and the children from that classroom did not leave the room or make any of the usual tumult. One of the other teachers asked what was going on. I joked about having hypnotized the children, but then told her to have a peek into the classroom and see what was going on. When she returned, she asked: "What have you done to them? There they are, all chewing, writing or looking at their textbooks." I answered that I had already explained: I hypnotized them. Everyone was amused, but my reputation suddenly improved.

This example shows that children like the divergent approach, that they learn better if we let them be children, to get involved and work independently. I am quite sure that they still know all there is to know about precipitation. In a traditional class, the teacher would have retold the content provided by the textbook, and then checked what they had remembered. In that model, children are the objects of the teaching process. The activity is done to them or at them. And of course, children do not like that, they do not want to be the object and the sufferer.

There are no dumb questions, but the answers do not have to be dumb either. These answers can be constructive. Roger Schank believes that often there is creativity in the construction of the explanation [64]. He believes that human creativity depends upon exactly the opposite process from what we are taught in school (1988). We can teach children to be creative by suggesting that they look for anomalies in the lesson materials [64, p. 127]. It was back in 1973 that David McClelland pointed out that people with special abilities (stars) aren't only talented in the cognition sphere, but primarily in the emotionalness sphere [45]. According to research, the students that had more self-confidence were more willing to speak when facing a risky situation [53]. They were not afraid they would look dumb in front of their peers. An experiment by Walter Mischel, a professor at Stanford University, proves this directly. He brought a group of fouryear-olds into a room with marshmallows on a table. He told them: "You can have one marshmallow each, but if you don't take one now and wait until I come back, you can have two marshmallows." When they reached the age of 20 , he established that the ones who refrained from taking a marshmallow right away had higher IQs, displayed more attentiveness and restraint, made friends more easily, had higher levels of self-control etc. [See: 31]. This only proves that those with higher levels of self-confidence, who believed they would get twice the sweets, had much netter personal performance.

It is false to assume that negative emotions always reduce creativity. Anger, rage and fear can instigate motivation, creativity, socialization etc. [31, p. 81]. Emotional control is not the same as holding back all emotions. For example, a person may get angry if we tell them that they cannot solve an issue. This might motivate them to think on the issue intensely and permanently, and to ultimately resolve it. Superior managers are more spontaneous than their mediocre peers [31, p. 81]. Resisting the despotic quality of moods is essential to our ability to work productively, to creativity [31, p. 83]. 
It is advisable to teach children in schools to constantly wonder whether what the teacher or textbook says makes sense. This approach is, however, unwelcome in today's education system. For example, as a student I had always wondered how it was possible to drill into the Earth to the depth of 2000 meters, causing a gush of black liquid, without a single piece of bone in it, because my teacher had explained that petroleum formed from the remains of dinosaurs and other large reptilians. Later, the discoveries made in organic chemistry of gasses has proven that it is possible for petroleum to form when certain gasses mix under high pressure. This is in direct contradiction to the hypothesis that god is the only and sacrosanct maker of life, and life is embodied in organic matter. If organic matter, as the body of life, could have originated through the interaction of physical forces, then the idea of god as the undisputed maker has been refuted, which does not suit the Vatican. Children today learn in schools that petroleum formed from the bacteria and algae deposited on the seabed, hence, from organic matter! Of course, I did not ask the question of the origin of petroleum, I did not ask how come there are no bones in the geysers of "black gold", because I knew it would have irritated the teacher. Now I wonder just how many dumb facts children must cram into their little heads just to earn their "damned" As.

To be creative, we must be willing to make mistakes [64]. Conservatism and conformity are in opposition to creativity [27], [52], [55]. Regardless of this fact, schools continue to generate conservatism and conformity. When a teacher writes the title of a lesson on the board and asks the students at the end of the class: "What have we learned today?", the answer usually comes from the conformists.

Being social means accepting the norms that govern society, the norms that others adhere to. Being creative means not accepting these norms. This is why some authors believe that creativity is antisocial [64]. One of the most important things children learn in schools is conformity. The stereotype is that the teacher "lectures", retells, "explains" the lesson, and the students are supposed to memorize, i.e. learn it. There is no room for student questions here, and generating questions is the most important aspect of creativity [64, p. 176]. Schools do not encourage students to ask questions, let alone train them how to do it. Every act of learning, reading, or dialogue generates numerous questions, but unfortunately, most of these questions are never answered [64, p. 175]. Questions initiate the creativity process [64, p. 176].

There are numerous definitions of creativity. For example, Robert Weisberg defines creativity as a process of innovation. "Creative thinking involves the intentional production of novelty, i.e. innovation generated as part of a goal-directed activity" [77, p. 7]. Weisberg's definition does not exclude divergent production. Ken Robinson gave a slightly better definition of creativity, but even that does not exhaust the quintessence of this notion. He sees creativity: (1) as the process of having original ideas that have (2) value [60, p. 151]. What does value here mean to Robinson? He left that questions unanswered. In most definitions of creativity, authors advocate the idea that a creative solution to a problem must be new (innovation) and that the new solution must be better than the old one. Guilford hinted at the possibility that the solution to the problem does not have to be better, but simply applicable [30]. He is the one who introduced the notion of divergent production. The solution need only be different, not necessarily better than the existing one. Divergent production is the foundation of creativity.

Creativity can be defined according to numerous criteria: Historical, cultural, evaluative, functional, based on hope, knowledge, overcoming of obstacles, passion, personality, responsibility, differences, self-expression etc. If for example, we take roles as a criteria for the definition, then we can talk about: (1) position, (2) function and (3) purpose [51, p. 75]. For example, the audience assigns creativity to the dancer, while neglecting the choreographer. The choreographer's purpose might be to present a storyline, and the dancer's to achieve artistic impression. If we tried to define creativity based on roles, it will turn out to be difficult work, and we always miss something. But still, there are some general features of creativity that are present in all the definitions: (1) a creative solution is always new and different than the ones before, (2) a creative solution is better than the existing ones, (3) creative is not the same as divergent and (4) a creative solution is always linked to emotions. In order to be creative in schools, children should be freed from restraints in terms of imagination. Teachers of today generally consider this approach to be a waste of time. There is a definition that follows the provided criteria. Creativity is the "interaction among aptitude, process, and environment by which an individual or group produces a perceptible product that is both novel and useful as defined within a social context" (Plucker et al., 2004, p. 90). Here we have the components of creativity. Namely, for a definition to be acceptable and comprehensive, it must not leave out any components of the notion. Radivoj Kvaščev builds on Guilford's ideas and singles out nine components of creativity: (1) originality, (2) spontaneous adaptable flexibility, (3) idea fluency, (4) expressive fluency, (5) associative fluency, (6) lexical fluency, (7) redefinition, (8) sensitivity to the issue and (9) elaboration (1980, p. 2). Here we can see that some of the definitions overlap. For example, expressive fluency, lexical fluency and elaboration. So, this range of components might be narrowed down to several elementary ones. What would be the criteria for narrowing them down? The same author gives the answer as well. Kvaščev believes that creativity requires that three conditions be met: (1) curiosity, (2) surprise and (3) wonderment [38, p. 139]. Surprise and wonderment always result in some emotions, and Kvaščev did not list emotionalness as a component of creativity [38, p. 2]. It is impossible to be creative without being curious. Surprise and wonderment go hand in hand with curiosity. School lessons are filled with new discoveries for the child and it is possible to usher it in through curiosity and wonderment.

Now we can ask what the characteristics are of creative people and whether these characteristics can be cultivated in a school environment. Even a cursory glance at these features makes it evident that they can indeed be fostered in a school environment. Mendelsohn and Gall listed seven relevant characteristics: (1) self-confidence, (2) personal adjustment, (3) achievement, (4) dominance, (5) deliberation, (6) altruism and (7) independence with non-suggestiveness [47]. 


\section{There Is No CREATIVITY Without EMOTIONALNESS}

When we ponder the participation of emotions and cognition in human creativity, it is easy to conclude that cognition is predominant and essential, but we must not forget that there is no creativity without emotions, even if they are manifested post factum. Sometimes a person performs creative acts expecting social affirmation or a specific form of recognition and reward for the creative act. The reward need not be social. It can be the internal satisfaction of the subject. Proof that cognition on its own is not sufficient can today be found in artificial intelligence (AI). Although rationality (cognition) is superior in AI than in humans (some believe by a factor of several billion), AI has not introduced any radical inventions into human society. For example, it has not resolved the issue of wireless energy transfer. Two facts are confusing: (1) that nowadays AI is built into most man-made innovations and (2) that the human civilization of today could not function without AI. Blinded by these two facts, some people (including some scientists) believe that creativity is exclusively rational, and that emotions are just an obstacle in the creative process. This is not true. Emotions can be a distraction, but cognition is subject to distraction as well.

There are many authors who see creativity primarily in the cognitive sphere. Just to name a few: [4], [16], [41], [62], [76]. There are, however, some that do not neglect emotions in the creative process [21], [24], [31], p63]. To be creative, we must be willing to make mistakes [64]. Conservatism and conformity are in opposition to creativity [27[, [52], [55]. Regardless of this fact, schools continue to generate conservatism and conformity.

This study aims to show that there is a correlation between creativity and emotions.

\section{OUR RESEARCH - METHODOLOGY}

\section{A. Sample}

A sample of 174 elementary schools students 11 to 14 years of age (49 fifth-grade students, 11-year-olds; 43 sixthgrade students, 12-year-olds; 44 seventh-grade students, 13year-olds and 38 eighth-grade students, 14-year-olds) from two schools in the urban area of Banja Luka (OŠ "Bora Stanković" and OŠ "Petar Petrović Njegoš") provided data through two instruments. Participation was voluntary with consent of the students and their parents. Two hundred sets of instructions were prepared. Two sets of tests were discarded because the students had not answered most of the questions, while 24 parents did not provide consent, so those children were excluded from the study. It should be noted that these 24 children reacted adversely to being excluded. The sample includes 89 boys and 85 girls. I used the $\chi 2$ tests on this ratio to calculate the significance of the difference. The test did not exhibit significant difference $(\chi 2=0.09$, significance level of $\mathrm{p}=0.76)$.

\section{B. Design}

The basic approach to the data-gathering was pen-paper. The students filled in printed tests, while the researcher was reading the tasks one by one. The students were asked to answer honestly and quickly. The classes, i.e., Groups to be tested were selected randomly. The students were asked to answer all the questions. The interviewer told them to put in answers that reflected their personality the closest.

\section{Instruments}

The study used two instruments: The CREM and the CogAT.

CREM is a proprietary instrument designed for this particular study (Suzić, 2020). In addition to general data on the students, this instrument contains: a) two questions that measure the students' feelings towards mathematics as a school course, b) nine questions from the field of logic, each accompanied by four emotions from Plutchik's (1980) categorization of eight primary emotions. The nine questions were taken from mathematics textbooks for all nine grades of elementary school, choosing tasks which the students could solve by merely following logic, without consulting a textbook or teacher. Each question was accompanied by a list of four emotions with a scale from 0 to 100: Happiness (joy), sadness (grief), fear (anxiety) and satisfaction (good mood). It is easy for students to distinguish the states of water $(0=$ water freezes, $100=$ water boils). Next to each task they were required to circle one of the 11 offered numbers, stating how intense the given emotion was when they were doing the task. The internal consistency for the nine mathematics problems, measured using Cronbach's alpha coefficient, was $\alpha=0.50$, which is quite low, but satisfies the criteria for academic evaluation because the tasks given were from all grades, i.e. from both above and below the interviewees' age. The internal consistency for positive emotions was very high $(\alpha=$ 0.83 ), and somewhat lower for negative emotions $(\alpha=0.78)$.

The $\operatorname{Cog}$ AT is a test with 54 items [15] distributed into three batteries: (1) verbal - 18 items, (2) quantitative -18 items and (3) non-verbal - 18 items. This test measures creativity primarily through the cognitive sphere. The internal consistency, or reliability of this instrument is sizeable $(\alpha=$ 0.83 ). This is a respectable level of consistency, measured using Cronbach's alpha coefficient.

\section{RESUlts}

The primary hypothesis was that there is a correlation between emotions and creativity. The hypothesis was accepted here, under the condition that the correlation be treated negatively, because all the correlations were negative, especially between emotions and creativity (Table 1, column 2 ; for joy $r=-0.23$; for sadness $r=-0.13$; for fear $r=-0.04$; for pleasure $r=-0.13$ ). The only ratio that was statistically significant was between joy and the creativity test (CogAT): $r=-0.23$, significance level of 0.001 ). This means that the more we rejoice over something, the less likely it is that there will be creativity involved. Indeed, we cannot say that Tesla's invention of the induction motor came out of joy.

TABLE I: CORRELATION (PEARSON'S) BETWEEN EMOTIONS AND CREATIVITY

\begin{tabular}{ccccc}
\hline & \multicolumn{5}{c}{$\operatorname{CogAT}$} \\
\cline { 2 - 5 } CREM & $\mathrm{r}$ & $\mathrm{Z}$ & $\mathrm{r}_{1}$ & $p(\mathrm{Z})$ \\
\hline CREM sum & $-0.41^{* *}$ & -11.44 & -0.88 & 0.000 \\
Happiness/Joy & $-0.23^{* *}$ & -9.22 & -0.71 & 0.000 \\
Sadness/Grief & -0.13 & -3.57 & -0.27 & 0.000 \\
Fear/Anxiety & -0.04 & -2.98 & -0.23 & 0.003 \\
Satisfaction/Good Mood & -0.13 & -9.58 & -0.74 & 0.000 \\
\hline
\end{tabular}

Note : CREM = CReativity and EMotions Test; $\operatorname{Cog} \mathrm{AT}=$ creativity test; reliability $(p)$ is applicable to value $\mathrm{Z}$. 
The value $\mathrm{r} 1$ was calculated following the $\mathrm{r} 1=\mathrm{Z} / \sqrt{\mathrm{n}}$ pattern [28], while value $\mathrm{Z}$ represents Wilcoxon' s pattern. The value $\mathrm{r} 1$ is actually the effect size of Pearson' $\mathrm{s}$ correlation coefficient. The data in Table I is very revealing. Working on the logic-based mathematics problems from textbooks (CREM) which require creativity is in negative correlation with the cognitive aspect of creativity $(r=-0.41$, significance level $\mathrm{p}=0.001)$. When students are asked to express their emotions on the work, the correlations remain negative (Table I, column 2). The calculation of the effect size shows that intensification of the emotions would increase this correlation in the negative score (Table I, column 4). This is an interesting phenomenon. This research has proven that the CogAT performance of students who have exhibited negative emotions and are below average is the same as the performance of students with positive emotions who are above average $(\mathrm{M}=0.80$; Table II). This was an unexpected finding, but I hoped that positive emotions would come after the tasks have been completed. I had relied on the manner, i.e. time of the work. During the testing, the children were asked to solve the problems and express their emotions afterwards. When I calculated the effects of this approach, nothing changed. It turned out that there were more students with positive emotions who were below average $(\mathrm{N}=114)$ than those with negative emotions who were below average $(\mathrm{N}=104)$. To make things more curious, the efficiency of those with negative emotions $(M=8.00)$ is higher than the efficiency of those with positive emotions who were below average $(\mathrm{M}=7.39)$. This convinced me that the authors who neglect emotions in analysis of creativity are, for the most part, right.

TABLE II: Performance of Students with Positive and Negative EMOTIONS IN THE CREM TEST

\begin{tabular}{ccccccccc}
\hline Test & Emotions & Mean & $\mathrm{N}$ & $\mathrm{M}$ & $\mathrm{SD}$ & $\mathrm{SE}$ & $\mathrm{t}$ & $\mathrm{p}$ \\
\hline \multirow{3}{*}{ Positive } & $>\mathrm{M}$ & 60 & 8.00 & 3.09 & 0.40 & \multirow{2}{*}{1.26} & \multirow{2}{*}{0.209} \\
& & & & \\
N & & 114 & 7.39 & 2.96 & 0.28 & & \\
& \multirow{2}{*}{ Negative } & $>\mathrm{M}$ & 70 & 7.02 & 2.63 & 0.31 & & \multirow{2}{*}{0.036}
\end{tabular}

Note $:$ CREM = creativity and emotions test; $\mathrm{N}=$ number of students; $\mathrm{M}=$ mean value; $\mathrm{SD}=$ standard deviation; $\mathrm{SE}=$ standard error.

The coefficient $\mathrm{Z}$ is a value from Wilcoxon's pattern which tells us how stable, or how variable, the correlation is. It is desirable to calculate this effect size whenever we test the stability of a correlation.

Schools are emotional deserts, as Flanders would say [28]. Having analysed the first data in this study, I decided to see if schools are dominated by negative emotions or perhaps there is no difference in the occurrence of positive and negative emotions. I decided to calculate the differences of the mean values (Table III), which showed that positive emotions were dominant

TABLE III: DifFERENCE OF MEAN VALUES BETWEEN POSITIVE AND NEGATIVE EMOTIONS (CREM)

\begin{tabular}{|c|c|c|c|c|c|c|}
\hline $\begin{array}{c}\text { Compared } \\
\text { pair }\end{array}$ & $\mathrm{N}$ & M & SD & $\mathrm{SE}$ & $\mathrm{t}$ & $\mathrm{p}$ \\
\hline $\begin{array}{l}\text { Positive } \\
\text { emotions }\end{array}$ & 174 & 24.55 & 21.51 & 1.62 & \multirow[b]{2}{*}{8.78} & \multirow[b]{2}{*}{0.000} \\
\hline $\begin{array}{l}\text { Negative } \\
\text { emotions }\end{array}$ & 174 & 8.85 & 10.13 & 0.77 & & \\
\hline
\end{tabular}

Note : CREM = creativity and emotions test; $\mathrm{N}=$ number of students; $\mathrm{M}=$ mean value; $\mathrm{SD}=$ standard deviation; $\mathrm{SE}=$ standard error. $(\mathrm{t}=8.78$; significance level $\mathrm{p}=0,001)$. This was also an unexpected result, so I thought the cause was the declarativeness of expressing views on emotions in schools, considering the fact that we are dealing with adolescents. I have noted this idea and left it for future research.

I was now interested in another question, which I had not set as a thesis of this study, because the answer requires longitudinal research. The question is whether there is a difference in expressing positive or negative emotions in younger or older student generations. Since this is not longitudinal research, the findings presented here are merely indications for future (longitudinal) studies.

\begin{tabular}{|c|c|c|c|c|c|}
\hline $\begin{array}{l}\text { Age } \\
\text { group } \\
\rightarrow\end{array}$ & & $\begin{array}{l}\mathrm{V}(11 \\
\text { years })\end{array}$ & $\begin{array}{l}\text { VI (12 } \\
\text { years) }\end{array}$ & $\begin{array}{l}\text { VII (13 } \\
\text { years) }\end{array}$ & $\begin{array}{c}\text { VIII } \\
(14 \\
\text { years })\end{array}$ \\
\hline $\mathrm{N} \rightarrow$ & & 49 & 43 & 44 & 38 \\
\hline \multirow{4}{*}{ Positive emotions } & M & 32.82 & 18.55 & 20.32 & 25.82 \\
\hline & $\mathrm{SD}$ & 27.87 & 10.79 & 19.10 & 20.40 \\
\hline & $\mathrm{SE}$ & 3.98 & 1.65 & 2.88 & 3.31 \\
\hline & $\mathrm{M}$ & 10.20 & 8.13 & 8.90 & 7.66 \\
\hline \multirow[t]{2}{*}{ Negative emotions } & $\mathrm{SD}$ & 11.83 & 7.40 & 8.90 & 11.94 \\
\hline & $\mathrm{SE}$ & 1.69 & 1.13 & 1.34 & 1.94 \\
\hline \multirow{2}{*}{$\begin{array}{c}\text { Difference of } \mathrm{M} \\
\text { between positive and } \\
\text { negative emotions }\end{array}$} & $t$ & 5.49 & 4.99 & 3.29 & 4.75 \\
\hline & $p$ & 0.000 & 0.000 & 0.002 & 0.000 \\
\hline
\end{tabular}

Note: $\mathrm{N}=$ number of students; $\mathrm{M}=$ mean value; $\mathrm{SD}=$ standard deviation; $\mathrm{SE}$ $=$ standard error.

Table IV shows that there is a statistically significant difference in favour of positive emotions against negative emotions. The result is consistent for all grades, i.e. age groups. It is a familiar fact that emotional intelligence significantly impacts performance in school [37]. I found that positive emotions are dominant in our schools, consistently for all age groups (Table IV). It remains to be seen whether positive emotions are in correlation with a high quotient of emotional intelligence. If we know that fear of failure significantly impedes learning [10], [37], [40], the question arises of what to do to oust negative emotions from classes. This study shows that fear is not a very strongly expressed emotion in classes, but that it is still present. One of the ways to get rid of the fear which I would suggest here is interactive learning, i.e. inclusion of the students into the teaching process, so that they would work on the lesson material themselves. Certainly, there are other methods, but this research has proven interaction successful. Studies have shown that emotions can be controlled in several ways: (1) emotions exhibited by the teacher while presenting stories [34], (2) film clips [11], (3) emotional speech [39], (4) images and comments on images [7], [14] etc. As for creativity, research indicates that emotions are part of creativity [36]. This study shows that emotions are part of creativity, but that they are not significant (Table I). It can be said that there is no difference in expressing emotions between younger and older students, but there is a difference in expressing positive and negative emotions (Tables III and IV).

These results have proven the proposition by Paul Ekman, Roger Schank and Peter Childers that the foundation of creativity is most often emotion [24], [64]. We cannot say it is only positive emotions, but we must take into account negative emotions as well. For example, Tesla carried his negative emotions on brushes and segmented fields on the rotor for several years, and ultimately found a solution in the 
form of magnetic field lines. Unfortunately, the school system is to a great extent still based on fear. It is a known fact that fear impedes motivation and restricts academic performance. It most commonly induces cognitive delusions and blockages [5], [9], [26]. In this study, fear is at quite a low level $(M=81.44)$, but it must be noted that it does occur during classes. The problem is all the more evident having in mind that some students exhibit fear at drastic levels. It has a negative correlation with creativity $(r=-0.04$; Table 1 , Column 2, penultimate line). Therefore, it is imperative that fear be removed from schools. The question arises if fear can be ousted from classes. Simple analysis is sufficient to answer this question with a yes.

\section{CONCLUSION}

This study has proven the set hypothesis that creativity is dependent on emotions, but the assumption remains that positive emotions occur upon reaching a creative solution to a problem. This is a topic for a new study, but it is not easy to find enough researchers who have creatively solved a problem and would be willing to express their emotions post factum.

The main contribution of this study is in creating a new instrument, CREM, and calibrating the CogAT instrument on a sample of elementary school students in Bosnia and Herzegovina. But still, the results are indicative.

- There is no positive correlation between emotions as the prerequisites of creativity. Rather, we can say that the correlation is primarily negative.

- Among school children, positive emotions are dominant.

- There is no statistically significant difference in expressing emotions between younger and older students, but there is a difference in expressing positive and negative emotions (Tables III and IV).

I have uncovered some other phenomena for further research.

- Can we eliminate fear as a negative emotion in schools? And how?

- If schools are dominate by positive emotions, why is it so?

- Do positive emotions occur upon solving a problem in a creative way?

- Can there be creativity without emotions?

Generally speaking, this study did not provide the expected answer to the question I asked before taking any concrete steps, but it did yield several valuable and useful ideas for future research. But still, the study confirmed a connection between creativity and emotions, especially in relation to the emotion of joy, or happiness. Truth be told, the correlation is negative $(r=-0.23$, significance level 0.001$)$. This is in fact logical, because one does not rejoice at a problem that has arisen, which is yet to be solved.

\section{REFERENCES}

[1] Ackers, M., \& Porter, G. (2003). Your EQ skills: Got what it takes. Journal of Accountancy, 195(3), 65-70.

[2] Аднађевић, Д. и Милић, Д. (2008). Математика за VII разред основне школе [Mathematics for the seventh grade of primary school]. Источно Сарајево, БиХ: Завод за уџбенике и наставна средства.

[3] Аднађевић, Д. и Милић, Д. (2010). Математика за осми разред основне школе [Mathematics for the eighth grade of elementary school]. Источно Сарајево, БиХ: Завод за уџбенике и наставна средства.

[4] Basador, M., Runco, M. A., \& Vega, L. A. (2000). Understanding how creative thinking skills, attitudes, and behaviors work together: A causal process model. Journal of Creative Behavior, 34(2), 77-100.

[5] Beck, A. T., \& Emery, G. (1985). Anxiety disorders and phobias: A cognitive perspective. New York, NY: Basic Books.

[6] Betts, J. A., Appleton, J. J., Reschly, A. L. Christianson, S. L., \& Huebner, E. S. (2010). A study of the factorial invariance of the student engagement instrument (SEI): Result from middle and high school students. School Psychology Quarterly, 25(2), 84-93.

[7] Broadley, M. M., Greenwald, M. K., Petry, M. C., \& Lang, P. J. (1992). Remembering pictures: Pleasure and arousal in memory. Journal of Experimental Psychology: Learning, Memory, \& Cognition, 18(2), 379-390.

[8] Brookfield, S. D. (1987). Developing critical thinkers: Challenging adults to explore ways of thinking and acting (pp. 71-85). Milton Keynes: Open University Press.

[9] Bower, G. H. (1981). Mood and memory. American Psychologist, 36(2), 129-148.

[10] Burgess-Wilkerson, B., Lampe, A., \& Frankforter, S. (2013). Emotional intelligence: A comparative analysis of two college business administration programs. Advances in Business Research, 4(1), 13-23.

[11] Cahill, L., Haier, R. J., Fallou, J., Alkire, M. T., Tang, C., Keator, D., Wu, J., \& McGaugh, J. L. (1996). Amygdala activity at encoding correlated with long-term, free recall of emotional information. Proceedings of the National Academy of Sciences, 93(15), 8016-8021

[12] Carlson, M., Charlin, V., \& Miller, N. (1998). Positive mood and helping behavior: A test of six hypotheses. Journal of Preschool Social Psychology, 55(2), 211-219.

[13] Chernis, C., \& Adler, M. (2000). Promoting emotional intelligence in organizations. Alexandria, VA: ASTD Press.2.

[14] Christianson, S. A., \& Fällman, L. (1990). The role of age on reactivity and memory for emotional pictures. Scandinavian Journal of Psychology, 31(4), 291-301.

[15] $\operatorname{Cog} A T$ (2020). The CogAT survival guide. Retrieved from: www.TestingMom.com. Accessed: 21 December 2020.

[16] Coney, J., \& Serna, P. (1995). Creative thinking for an information processing perspective: A new approach to Mednik's theory of associative hierarchies. Journal of Creative Behavior, 29(2). 109-131.

[17] Connell, J. P., \& Wellborn, J. G. (1991). Competence, autonomy, and relatedness: A motivational analysis of self-system processes. In M. R. Gunnar \& L. A. Sroufe (Eds.), Self-processes and development (Vol 23, pp. 43-78). Hillsdale, NJ: Erlbaum.

[18] Connolly, P. (2007). Quantitative data analysis in education: A critical introduction using SPSS. New York, NY: Routledge.

[19] Csikszentmihalyi, M. (1996). Creativity. New York, NY: Harper Collins.

[20] Csikszentmihalyi, M. (1997). Finding flow: The psychology of engagement with everyday life. New York, NY: Basic Books.

[21] Damasio, A. R. (1994). Descartes' error: Emotion, reason, and the human brain. New York, NY: Avon Books.

[22] Eisenberg, N. (2000). Emotion, regulation, and moral development. Annual Review of Psychology, 51, 665-697.

[23] Eisenberg, N., Fabes, R. A., Nyman, M., Bernzweig, J., \& Pinueals, A (1994). The relations of emotionality and regulation to children's anger-related reactions. Child Development, 65(1), 109-128.

[24] Ekman, P. (2003). Emotions revealed: Recognizing faces and feelings to improve communication and emotional life. New York, NY: Times Books.

[25] Elklit, A. (1991). Univerzitetska nastava kao propovedni ritual [University teaching as a preaching ritual]. In Č. Nedeljković (Ed.) Putevi obrazovanja: Strana iskustva [Paths of education: Foreign experiences] (p. 189-202). Beograd, Srbija: Saša Nedeljković.

[26] Eysenck, M. W. (1992). Anxiety: The cognitive perspective. Hove, UK Erlbaum.

[27] Feist, G. J., \& Brady, T. (2004). Openness to Experience, NonConformity, and the Preference for Abstract Art. Empirical Studies of Arts, 22(1), 77-89.

[28] Flanders: N. A. (1970). Analyzing teaching behavior. Reading, Massachusetts: Addison-Wesley Publishing.

[29] Frick, P. J. (1998). Callous-unemotional traits and conduct problems: Applying the two-factor model of psychopathy. In D. J. Cooke, A. Forth et al., (Eds.), Psychopathy: Theory, Research and Implications for Society (pp. 161-187). Amsterdam, Netherlands: Kluwer Academic. 
[30] Guilford, J. P. (1950). Creativity. American Psychologist, 5(9), 444454.

[31] Goleman, D. (1998). Working with emotional intelligence. New York, NY: Bantam Books.

[32] Goleman, D., Boyatris, R., \& McKee, A. (2002). Primal leadership: Realizing the power of emotional intelligence. New York, NY: Bantam Books.

[33] Grant, W. (1997). Resolving conflicts: How to turn conflict into cooperation? Shaftesbury, UK: Element Books Limited.

[34] Heuer, F., \& Reisberg, D. (1990). Vivid memories of motivational events: The accuracy of remembered minutiae. Memory \& Cognition, 18(5), 496-506.

[35] Jurić, V. (1974). Učenikovo pitanje u suvremenoj nastavi [The student's question in modern teaching]. Zagreb, Hrvatska: Školska knjiga.

[36] Kaufman, S. B. (2013). Opening up openness to experience: A fourfactor model and relations to creative achievement in the arts and sciences. Journal of Creative Behavior, 47(4), 233-255.

[37] Kanfer, R., Ackerman, P. L., \& Heggestad, E. D. (1996). Motivational skills and self-regulation for learning: A trait perspective. Learning and Individual Differences, 8(3), 185-209.

[38] Kvaščev, R. (1980). Podsticanje i sputavanje stvaralačkog ponašanja ličnosti [Encouraging and restraining the creative behavior of a person]. Sarajevo, BiH: IGKRO "Svjetlost", OOUR Zavod za udžbenike.

[39] LaBar, K. S., \& Phelps, E. A. (1998). Arousal - mediated memory consolidation: Role of the medial temporal lobe in humans. Psychological Science, 9(6), 490-493.

[40] Lam, L., \& Kirby, S. (2002). Is emotional intelligence an advantage? An exploration of the impact of emotional and general intelligence on individual performance. Journal of Social Psychology, 142(1), 133143

[41] Lonergan, D. C., Scott, G. M., \& Mumford, M. D. (2004). Evaluative aspects of creative thought: Effects of idea appraisal and revision standards. Creative Research Journal, 16(2-3), 231-246.

[42] Low, G., Lomax, A., Jackson, M., \& Nelson, D. (2004). Emotional intelligence. A now student model. A paper presented at the National Conference of the American College Personnel Association. Philadelphia, Pensylvania.

[43] Mayer, R. E. (2006). The role of domain knowledge in creative problem solving. In J. C. Kaufman \& J. Bear (Eds.), Creativity and reason in cognitive development (pp. 145-158). New York, NY: Cambridge University Press.

[44] Mayers, L. L., \& Tucker, M. L. (2005). Increasing awareness of emotional intelligence in a business curriculum. Business Communication Quarterly, 68(1), 44-51.

[45] McClelland, D. C. (1973). Testing for competence rather than intelligence. American Psychologist, 46(1), 1012-1024.

[46] McPartland, J. M. (1994). Dropout prevention in theory and practice. In J. K. Rossi (Ed.), Schools and students at risk: Context and framework for positive change (pp. 255-276). New York, NY: Teachers College Press.

[47] Mendelsohn, G., \& Gall, M. (1970). Personality variables and the effectiveness of techniques to facilitate creative problem solving. Journal of Personality and Social Psychology, 16(2), 346-351.

[48] Мићић, Б. (2017). Математика за 5. разред основне школе [Mathematics for the 5th grade of primary school]. Источно Ново Сарајево, БиХ: ЈП Завод за уджбенике и наставна средства.

[49] Milivojević, Z. (2007). Emocije: Psihoterapija i razumevanje emocija [Emotions: Psychotherapy and understanding emotions]. Novi Sad, Srbija: Psihopolis.

[50] Mischel, W. \& Ebbesen, E. B. (1970). Attention in delay of gratification. Journal of Personality and Social Psychology. 16(2), 329-337.

[51] Moran, S. (2010). The role of creativity in society. In J. C. Kaufman \& R. J. Sternberg (Eds.), The Cambridge handbook of creativity (pp. 7490). New York, NY: Cambridge University Press.

[52] Nettle, D. (2006). Schizotypy and mental health amongst poets, visual artists and mathematicians. Journal of Research in Personality, 40(6), 876-890.

[53] Parker, L. E. (1993). When to fix it and when to love: Relationship among perceived control, self-efficacy, dissent, and exit. Journal of Applied Psychology, 78(6), 949-959.

[54] Peale, N. V. (1994). Moć pozitivnog mišljenja [The power of positive thinking]. Novi Sad. SR Jugoslavija: Global Book.

[55] Peterson, B. E., \& Pang, J. S. (2006). Beyond politics: Authoritarianism and the pursuit of leisure. Journal of Social Psychology, 146(4), 443461.

[56] Plucker, J. A., Beghetto, R. A., \& Dow, G. (2004). Why isn't creativity more important to educational psychologist? Potential, pitfalls, and future directions in creativity research. Educational Psychologist, 39(2), 83-96.

[57] Plutchik, R. (1980). A general psychoevolutionary theory of emotion. In R. Plutchik \& H. Kelerman (Eds.), Emotion, Theory, Research, and Experience: Vol. 1. Theories of Emotion (pp. 3-33). New York, NY Academic.

[58] Quigley, B. M., \& Tadeschi, J. T. (1996). Mediating effects of blame attributions on feelings of anger. Preschool Social Psychology Bulletin, 22(3), 1280-1288.

[59] Richards, A., French, C. C., Calder, A. J., Webb, B., Fox, R., \& Young, A. W. (2002). Anxiety-related bias in the classification of emotionally ambiguous facial expressions. Emotion, 2(3), 273-287.

[60] Robinson, K. (2011). Out of our minds: Learning to be creative, fully revised and updated edition. West Sussex, UK: Capstone.

[61] Rot, N. (1980). Osnovi socijalne psihologije: Socijalizacija [Fundamentals of social psychology: Socialization]. Beograd, Srbija Zavod za udžbenike i nastavna sredstva.

[62] Runco, M. A. (2006). Reasoning and personal creativity. In J. C. Kaufman \& J. Bear (Eds.), Creativity and reason in cognitive development (pp. 99-116). New York, NY: Cambridge University Press.

[63] Salovey, P., \& Mayer, J. (1990). Emotional intelligence. Imagination, Cognition and Personality, 9(3), 198-211.

[64] Schank, R., \& Childers, W. P. (1988). Creative attitude: Learning to ask and answer the right questions. New York, NY: MacMillan Publishing Company.

[65] Schunk, D. H., \& Zimmerman, B. J. (Eds.), (1994). Self-regulation of learning and performance: Issues and educational applications. Hillsdale, NJ: Erlbaum.

[66] Shiopuri, S., \& Kim, B. (2004). Do employers and colleges see eye-toeye? College student development and assessment. NACE Journal, $65(1), 33-44$.

[67] Spector, P. E. (1997). The role of frustration in antisocial behavior at work. In R. A. Jiacalone \& J. Greensberg (Eds.), Anti-social behavior in organizations. (pp. 1-17). Thousand Oaks, CA: Sage.

[68] Spengler, O. (1923). Der Untergang des Abendlanders: Umrisse einer Morphologie der Weltgeschichte: München, GDR: C. H. Beckshire Verlagsbuchhandlung Oskar Beck.

[69] Стојановић, В. (2008). Математика за девети разред основне школе [Mathematics for the ninth grade of elementary school] Источно Сарајево, БиХ: Завод за уџбенике и наставна средства.

[70] Suzić, N. (2005). Pedagogija za XXI vijek [Pedagogy for the 21st Century]. Banja Luka, RS, BiH: TT-Centar

[71] Сузић, Н. и Антић, Д. (2007). Афективни стилови у настави [Affective styles in teaching]. Настава и васпитање, 56(3), 227-243.

[72] Шапиро, Л. Е. (1998). Емоционална интелигенција - како васпитањем добити дијете са високим EQ [How to raise a child with a high EQ]? Београд, Србија: Народна књига - Алфа

[73] Šindić, A. and Suzić, N. (2010). Emocionalno opismenjavanje predškolskih otrok [Emotional literacy of preschool children]: Prikasz eksperimentalnega raziskovanja. Moderna znanstvena konferenca Opismenjavanje učenik in učencev, pismenost mladih $i$ odraslih vprašanja, dileme, rešitve (p. 50-62). Žalec, Slovenija: Zveza društev pedagoških delavcev Slovenije.

[74] Tiwari, A., Lai, P., So, M., \& Yuen, K. (2006). A comparison of the effects of problem-based learning and lecturing on the development of students critical thinking. Medical Education, 40(6), 547-554.

[75] Тошић, Р. и Стојановић, В. (2011). Математика за шести разред основне школе [Mathematics for the sixth grade of elementary school]. Источно Сарајево, БиХ: Завод за уџбенике и наставна средства.

[76] Urban, K. K. (2003). Toward a componential model of creativity. In D. Ambrose, L. M. Cohen, \& A. J. Tannenbaum (Eds.), Perspectives in creativity. Creative intelligence: Toward theoretic integration (pp. 81112). Washington, DC: Hampton Press.

[77] Weisberg, R. W. (2006). Expertise and reason in creative thinking. Evidence from case studies and the laboratory. In J. C. Kaufman \& J. Bear (Eds,), Creativity and reason in cognitive development (pp. 7-42). New York, NY: Cambridge University Press.

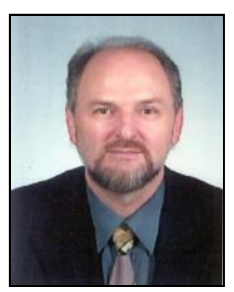

Nenad Suzic was born on October 11th, 1950 in Prusci, Novi Grad, Bosnia, and Herzegovina. Following his initial vocational training for teachers, he graduated from the Faculty of Philosophy in Zagreb, Croatia with a degree in pedagogy and sociology (BA). He received his MA degree at the Faculty of Philosophy in Zagreb, Croatia, while his Ph the Faculty of Philosophy in Belgrade, Serbia. 
From 1970 to 1971 he worked as elementary school teacher (grades to 4) and subject teacher. He worked as a school counselor (pedagogue) in Novi Grad Vocational High School between 1976 and 1981. From 1981 to 1993 he taught lessons in sociology and psychology to secondary school children. Soon he was appointed as the deputy school principal, and later as the principal at the same Vocational High School. Right after his position of the school inspector at the Republika Srpska Institute of Pedagogy (1993-1996), he began teaching at the Faculty of Philosophy in Banjaluka.. He was also the Minister of Education in the Republika Srpska Government from 1998 to 2000. During his tenure as the university professor, he has taught Pedagogy and Sociology of Education. After the Government employment as a Minister of Education, he continued his involvement in Facutly of Philosophy of University of Banja Luka as a full time professor at department of Educational sciences - Pedagogy. He published 30 books and 215 manuscripts, from which $30 \%$ have international published character. 